\title{
OS DESAPARECIDOS, OS FANTASMAS E O CORPO COMO ARQUIVO

\author{
Analisando o conflito sírio na performance contemporânea
}

\author{
THE “DESAPARECIDOS”, THE GHOSTS AND THE BODY AS \\ ARCHIVE \\ Analyzing the Syrian conflict in contemporary performance
}

\author{
Silvia Raposo \\ Universidade NOVA de Lisboa, Faculdade de Ciências Sociais e Humanas (NOVA/FCSH), Centro em Rede de \\ Investigação em Antropologia (CRIA), CRIA, Av. Forças Armadas, Edifício ISCTE-IUL, sala 2W2, 1649-026 \\ Lisboa, Portugal. Email: silvia961993@gmail.com
}

\begin{abstract}
Resumo: O presente artigo propõe uma análise da dança-teatro partindo do binómio performance/política no qual se perspetiva o corpo como lugar privilegiado para a análise do poder. Para tal recorre-se aos espectáculos Antes que matem os elefantes, da Companhia Olga Roriz, e Eu Sou Mediterrâneo, da Companhia Vidas de A a Z, no seu percurso artístico e analisa-se as suas linguagens coreográficas e cénicas tendo em vista uma compreensão da performance como um lugar de tensão e embates que desenvolve articulações com a memória e esquecimento num jogo sensório-corporal. Empreende-se, assim, uma análise à política do chão como modo de compreender a performance da violência nos corpos "sem órgãos" das Companhias Olga Roriz e Vidas de A a Z, interpretando o chão em que se dança/interpreta como espaço que propõe uma arqueologia da violência sobre os corpos, transformando-os num microcosmo da guerra. $\mathrm{O}$ corpo é aqui entendido enquanto um "arquivo" do conflito sírio que permite recuperar as "versões fracas" através da libertação de "fantasmas" assumindo-se enquanto micro-resistência.
\end{abstract}

Palavras-chave: performance, memória, guerra civil síria, matérias-fantasma.

\begin{abstract}
This article proposes an analysis of dance-theater based on the performance/political binomial in which the body is seen as a privileged place for the analysis of power. To this end, the show Antes que matem os elefantes, by the Olga Roriz Company and Eu Sou Mediterrâneo, from Vidas de A a Z, are analyzed in its artistic course and its choreographic and scenic languages in order to understand performance as a place of tension and clash that develops articulations with memory and forgetfulness in a sensory-corporal game. Thus, an analysis of the politics of the ground is undertaken as a way of understanding the performance of violence in the bodies "without organs" of the companies Olga Roriz and Vidas de A a Z, interpreting the floor in which they dance/interprets as a space that proposes an archeology of violence over bodies, transforming them into a microcosm of war. The body is understood here as an "archive" of the Syrian conflict that allows to recover the "weak versions" through the liberation of "ghosts" assuming itself as micro-resistance.
\end{abstract}

Keywords: performance, memory, Syrian civil war, ghostly matters.

\section{Introdução ${ }^{1}$}

Damasco mede o tempo não pelos seus dias e meses e anos, mas pelos Impérios que viu crescer, prosperar e desintegrarem-se em ruínas. (Twain, como citado em Chagas, 2014, p. 407) 
Cada vez mais as práticas artísticas contemporâneas têm como foco temático a actual conjuntura político-social europeia, caracterizada pela escalada do Jihadismo global, que tem adquirido uma maior visibilidade nos últimos anos com a expansão do DAESH, e do "terrorismo insurgente" (Galito, 2013); pela Guerra Civil Síria (2011 - presente) e consequente crise mundial de refugiados que nos confrontam com uma crescente violação dos direitos humanos tanto no seio das sociedades em conflito armado, como nas que se deparam com vozes de culturas dissonantes, evidenciadas nas novas sociedades multiculturais, nas quais a instrumentalização dos direitos humanos se vê cada vez mais declarada, fazendo com que os conceitos de "orientalismo" e "choque de civilizações" regressem à arena política (Huntington, S.d; Said, 1995).

O conflito na Síria teve início em 2011, como resultado das "Primaveras árabes", levantamentos populares contra os regimes ditatoriais no Oriente Médio e norte da África que tiveram início a 18 de dezembro de 2010 quando o tunisiano Mohamed Bouazizio ateou fogo às suas vestes imolando o próprio corpo em forma de protesto contra a corrupção e repressão policial (Andrade, 2011), desenvolvendo-se dentro de um paradigma em que a violência deixou de se subordinar ao poder para ela própria passar a ser um fim (Arendt, 2014). O declínio do poder do governo sírio abriu espaço à violência, tanto do próprio governo sobre a população numa tentativa de manter o poder, como pelos grupos de libertação e pelo DAESH. Posto isto, a guerra civil que assola a Síria, com uma posição estratégica no Médio Oriente, resultou numa crise humanitária a nível mundial.

Mediante esta nova figura do exótico que goza de um aglomerante impacto mediático perpetuado pela comunicação social, vários agentes artísticos mobilizaram a versão histórica e mediática da Guerra Civil Síria como forma de mise-en-scène do drama social, posicionando-se face à actual conjuntura político-social do Médio Oriente e Europa, dos quais são exemplo os estudos de caso que irei apresentar de seguida, reportando-me aos espectáculos Antes que matem os elefantes, da Companhia Olga Roriz, e Eu Sou Mediterrâneo, da Companhia Vidas de A a Z. Mais se refere que o cerne do artigo visa responder às seguintes questões: de que modo se performa um lugar? O que revelam as performances situadas acerca do chão que habitam? De que modo o chão da performance pode refletir o mundo social ou constituir-se como contra-lugar? Que chão é este em que os artistas dançam/interpretam? Em que chão querem dançar/interpretar? E que matérias-fantasma brotam deste chão? Parte-se, assim, dos dois estudos de caso que considerei representativos de uma abordagem artística ao Jihadismo global e à Guerra Civil Síria (2011 - presente), nomeadamente, os espectáculos: Eu Sou Mediterrâneo: um espectáculo sobre a banalidade do mal, da Companhia Vidas de A a Z, que estreou a 2 
de Junho de 2016 no Teatro Turim, em Benfica (Lisboa), e passa por uma abordagem ao fenómeno do Jihadismo Global e à Guerra Civil Síria através do teatro; e o espectáculo Antes que matem os elefantes da Companhia Olga Roriz, que esteve em cena de 15 a 16 de Julho de 2016 no Teatro Camões, no Parque das Nações (Lisboa), onde também é feita uma abordagem à Guerra Civil Síria (2011 - presente) através da dança. A etnografia resulta de uma investigação de cerca de dois anos, onde se cruzou a investigação etnográfica com a história das companhias e as biografias pessoais dos intérpretes através da pesquisa documental, testemunhos orais (conversas informais com os interlocutores), testemunhos escritos (nove testemunhos por escrito dos artistas/intérpretes e cinco notas por parte da encenação), entrevista etnográfica (cinco entrevistas, duas destas em grupo) e um processo de pesquisa no terreno que teve início com o acompanhamento dos ensaios no estúdio, nos teatros e nos bastidores.

Se Ervin Goffman introduz o teatro como uma metáfora para a vida quotidiana (Goffman, 2011), aqui procurou-se etnografar a vida quotidiana no teatro como proposta de uma investigação antropológica e, neste sentido, a noção de "bricolage" levistraussiana, tal como recuperada por Atkinson (2010), apresentou-se como fundamental para a compreensão dos processos de criação colectiva. Investigou-se, deste modo, o processo através do qual o texto dramatúrgico é transformado em performance artística pelo encenador na sua interação com os artistas, bem como a forma como os artistas transformaram as ideias em acções concretas a partir de um enquadramento interpretativo mobilizado pelo encenador/coreógrafo.

Ainda, ao longo deste processo de partilhas e vivências a minha presença permitiu a criação particular de um lugar de "escuta terapêutica" ou "lugares de escuta", como destaca Santinho parafraseando Fassin (Santinho, 2009, p. 585), no sentido em que os interlocutores partilharam comigo as suas histórias, algumas associadas a dores e narrativas de traumas pessoais (sempre entendidas enquanto construções culturais e sociais da memória pessoal e colectiva), mas também medos e angústias profissionais, por vezes partilhando também os seus "silêncios de histórias que foram vividas para não ser contadas", mas também "a expectativa de um futuro renovado" (Santinho, 2009, p. 585), permitindo destacar o lugar da performance enquanto terapia e forma de "tocar o fantasma" (Gordon, 1997). Para a entrevista etnográfica recorri a uma amostragem intencional (Burgess, 1997), sendo os meus interlocutores artistas (actores e bailarinos) que estavam a trabalhar nas produções cénicas da coréografa Olga Roriz e da encenadora Mónica Gomes. Já o trabalho documental em ambos os estudos de caso consistiu na recolha de vários tipos de documentos (folhas de sala, guiões, cartazes, desenhos de luz, designs de figurinos, etc.), para a qual o limite temporal dessa investigação se definiu a partir 
da história das companhias e dos tempos históricos mobilizados nos e pelos espectáculos.

Uma perspectiva diacrónica na análise destes documentos foi fundamental para compreender as dinâmicas internas dos processos de criação performativa que se encontravam em permanente reconstrução e renegociação pelos diferentes participantes.

Posto isto, a partir dos referidos estudos de caso pretende-se compreender o modo como a partir do espaço da performance se abre um espaço de negociação de significados e mnemónicas associadas aos objetos e lugares de memória coletiva do conflito sírio, que procura articular uma memória coletiva de experiências traumáticas com a prática artística, transformando a cena num "museu vivo" de uma memória coletiva e mediática da Guerra Civil Síria, tendo em vista a resistência subalterna e agência cultural. Neste sentido, dentro do binómio performance/política, os estudos de caso permitiram-me perspetivar o corpo como lugar privilegiado para a análise do poder, no sentido em que este sofre sempre as acções das relações de poder, transformando-se num lugar de tensão e embates. Deste modo, proporcionam-nos uma leitura do corpo como veículo de contestação por quem ousa criticar e propor novas formas de se relacionar com o mundo.

\section{Por uma política do chão}

No âmbito de uma proposta que procura reconhecer o chão da performance enquanto superfície refletora do mundo social, torna-se relevante evidenciar uma lente teórica que, na área da sociologia e de outras ciências sociais, sustenta um olhar sobre a sociedade como uma "sociedade do espectáculo" (Debord, 2003) marcada por uma performance do mundo social em que toda a actividade humana é performativa, inclusive os recursos linguísticos, e as relações sociais são mediadas por performances que procuram as suas manifestações no campo da "fachada" (Goffman, 2011; Schechner, 2006) e contribuem para legitimar as estruturas do poder através de uma "teatrocracia" que sustenta o fosso entre governantes e governados (Balandier, 1982; Debord, 2003). Uma sociedade onde irrompem episódios de conflito e de tensão - "dramas sociais" (incluindo fontes de forma estética) -, que se apresentam como um "metateatro", um espaço simbólico de representação da realidade social que permite aos actores sociais estarem à "margem" da sociedade e recorre à inversão de papéis, tornando-se um espaço simultaneamente reflexivo onde as estruturas de experiência grupal são copiadas, desmembradas e ressignificadas (Turner, 1986) e onde se denuncia a forte relação entre performance, política e resistência. 
Neste sentido, é relevante compreender que a noção de coreografia ou encenação geralmente se baseia numa fantasia de que o chão da dança ou da performance é um espaço em branco, liso, sendo que na maioria das vezes se ignora a violência contida no acto de neutralizar um espaço. A principal condição para a dança ou a representação acontecerem não é o corpo, o movimento ou a música e cenografia, mas sim, como sugere Lepecki, a "terraplanagem", o alisamento prévio do chão onde esta tomará forma (Lepecki, 2011). Para que uma performance aconteça sem tropeções é necessário um chão liso, calcado e recalcado (Lepecki, 2013), uma vez que o som que anima e precede a dança, o movimento, não é o canto dos pássaros, mas as convulsões da história na superfície da terra, ou seja, cicatrizes de historicidade: "A barulheira infernal da maquinaria pesada, o palavrar ou as canções de trabalho dos operários, o chincalhar das ferramentas, o vociferar e os comandos de topógrafos, engenheiros e capatazes. E também, os gritos dos escravos" (Lepecki, 2013, p. 113).

O intérprete só deveria entrar em cena após o chão se tornar liso, para que a sua actuação não tenha de negociar com os acidentes de percurso. Contudo, a performance contemporânea tem vindo a desenvolver uma relação com esse chão supostamente neutro, propondo uma arqueologia da violência que faça tropeçar o intérprete apesar de todos os alisamentos, sendo esse tropeço o símbolo do encontro com a historicidade do chão onde se dança ou interpreta. Trata-se de pensar planos de composição para uma "política do chão" (Lepecki, 2013).

Quando se fala em "política do chão" na performance sugere-se um plano de composição que se enlaça entre o corpo e o lugar, nos seus interstícios. O chão surge como um lugar de força, transitório, liso. Um contra-lugar entre o corpo e o lugar (Vier Munhoz, 2015). Precisamente entre o corpo e o lugar encontramos o chão. Um espaço que esconde armadilhas para os corpos que não se submetam ao movimento imposto pelo território. Mas, como nos recorda Deleuze, o chão pode ser estriado como ter a lisura de um deserto (Vier Munhoz, 2015), sendo que o espaço liso é habitado por uma multidão de intensidades: "O que ocupa o espaço liso são as intensidades, os ventos, os ruídos, as forças e as qualidades tácteis e sonoras, como no deserto, na estepe ou no gelo" (Deleuze \& Guattari, 1997, p. 185, como citado em Vier Munhoz, 2015).

O corpo enquanto gesto dançante ou interpretado é pensado nesse chão liso. É a lisura aquilo que permite que o movimento aconteça, deslize, contraia, retraia ou até mesmo recuse a ocupar o espaço. Mas todo o chão liso está imbuído de cicatrizes através das quais podemos escorregar e tropeçar. Por esse motivo, Deleuze e Guattari argumentam que os dois espaços não existem um sem o outro: o espaço liso é constantemente convertido num espaço estriado e o espaço estriado é constantemente devolvido a um espaço liso (Vier Munhoz, 2015). 
É precisamente a forma com que nos relacionamos com o espaço que determina o modo como o produzimos (Vier Munhoz, 2015). O corpo na sua relação com o chão efetua uma forma específica de movimento e neste sentido Paul Carter refere-se ao conceito de "política do chão":

Para Carter, a política do chão não é mais do que isto: um atentar agudo às particularidades físicas de todos os elementos de uma situação, sabendo que essas particularidades se coformatam num plano de composição entre corpo e chão chamado história. (Lepecki, 2011, p. 47)

Neste sentido, dançar ou deslocar-se pelas cicatrizes que se abrem no chão e transitar pelos espaço lisos, movimentar-nos por relações intransitivas entre o corpo e o lugar é um gesto de resistência à ordem das coisas (Vier Munhoz, 2015). Posto isto, no sentido de esclarecer estas cicatrizes que surgem no chão liso e compreender as particularidades de uma "política do chão", saliento a noção de "haunting" associada ao conceito de "matérias-fantasma", evocada por Avery Gordon (1997), a que irei voltar mais adiante:

[Falar de assombrações é falar em milhares de fantasmas]; Quando sociedades inteiras ficam assombradas por atos terríveis que ocorrem sistematicamente e são simultaneamente negados por todos os órgãos públicos do governo e comunicação; Quando todo o propósito da negação verbal é garantir que todos saibam o suficiente para assustar a normalização no sentido de causar um estado de cansaço nervoso; Quando há fantasmas inocentes e fantasmas malévolos que vivem em bairros; (...) Quando as pessoas que conhecemos ou amamos estão lá num minuto e desaparecem no próximo; (...) Quando um prédio comum pelo qual passamos todos os dias abriga uma fachada que separa o grito das suas atividades terroristas da fala silenciosa de terríveis conversas; Quando toda a vida se tornou tão envolvida no trânsito dos mortos e dos mortos-vivos... Abordar, muito menos estabelecer, uma compreensão firme dessa realidade social pode fazer-nos sentir como se estivéssemos a carregar o peso do mundo aos nossos ombros. (Gordon, 1997, p. 64)

André Lepecki reivindica o conceito de "matérias-fantasma" (Gordon, 1997; Lepecki, 2013) para criar uma "política do chão", sendo que na sua acepção, as "matérias-fantasma" são:

todos aqueles fins que ainda não terminaram (...), o fim da escravatura que não terminou com a escravidão; o fim da colônia que não terminou com o colonialismo; a morte de um ente querido que não apaga a sua presença; o fim de uma guerra que não deixou de ser ainda perpetrada. (Lepecki, 2013, p. 114) 
A virtualidade do fantasma está em actuar como contemporâneo do presente, mas as matérias-fantasma são também todos os "corpos impropriamente enterrados da história" (Gordon, 1997; Lecpecki, 2013, p. 114), ou seja, os corpos que foram negligenciados, enterrados, descartados e esquecidos pela história no espaço mais neutro, no terreno mais liso que agora brotam do chão provocando desequilíbrios e quedas e transformando esses espaços lisos num terreno difícil de dançar ou movimentar. Quero com isto referir que, para além da intencionalidade coreográfica, por vezes esses terrenos lisos expulsam "matérias-fantasma" obrigando esta a escorregar e a romper com a ilusão da neutralidade do espaço e do nosso corpo e movimento no mesmo (Gordon, 1997; Lepecki, 2013).

Uma política cénica ou coreográfica do chão corresponderia à forma como a encenação determina o modo como os intérpretes fincam os pés nos chãos que os sustentam e como os chãos sustentam diferentes posicionamentos e historicidades transformando-as e transformando-se (Lepecki, 2011). Os estudos de caso que me proponho a analisar posicionam-se precisamente num chão por onde irrompem inúmeras "matérias-fantasma" e, neste sentido, procurar-se-á uma compreensão do espaço cénico como "lugar de memória" (Nora, 1993) e chão por onde irrompe as "assombrações" e os "desaparecidos" (Gordon, 1997) associados à Guerra Civil Síria e ao Jihadismo Global.

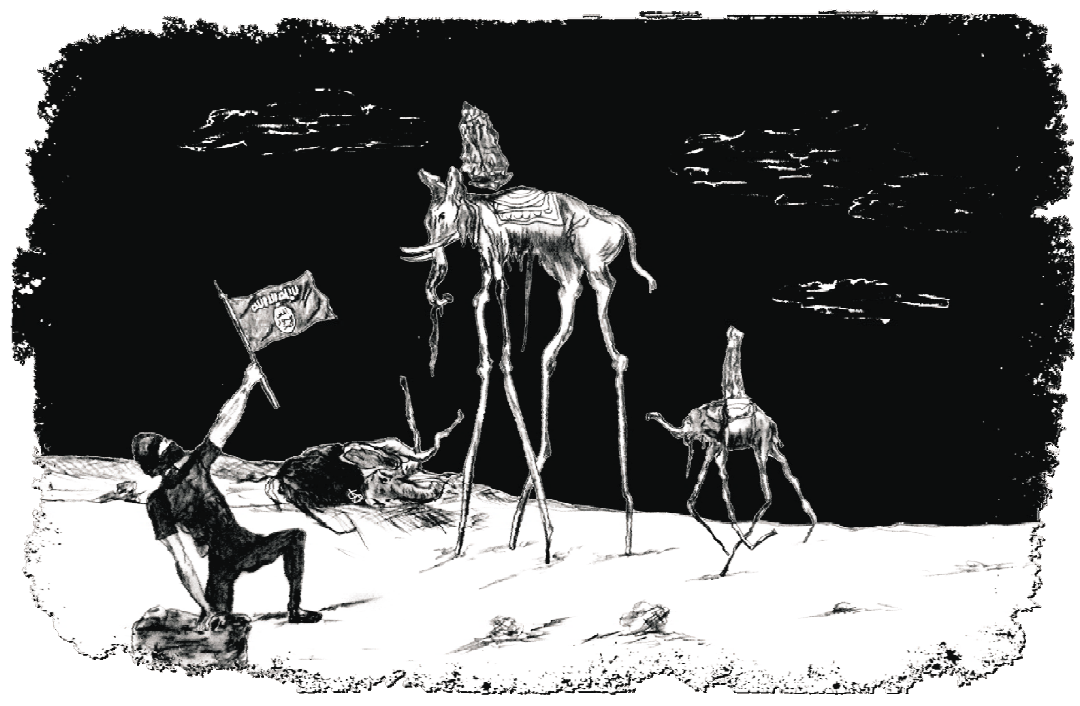

Figura 1 Chão de marfim

Fonte: ‘ Sílvia Raposo. 


\section{A primavera por florir - Uma performance do drama social sírio}

O espectáculo Antes que matem os elefantes subiu à cena a 15 e 16 de Julho de 2016 no Teatro Camões, em Lisboa, e procura ser um alerta para uma reflexão coletiva sobre o conflito na Síria. O espectáculo havia estreado a 29 de Abril, em Aveiro, no Centro Cultural de Ílhavo, tendo como temas centrais os refugiados, as migrações e a guerra. Os bailarinos, Beatriz Dias, Carla Ribeiro, Francisco Rolo, Marta Lobato Faria, André de Campos, Bruno Alexandre e Bruno Alves dão corpo a um grupo de pessoas que procuram um lugar e corporizam emoções, memórias, medos e inseguranças relacionadas com as migrações forçadas. E embora o espectáculo incida sobre a temática do conflito sírio, a história do espectáculo é sobre um grupo de pessoas que procuravam um lugar porque neste mundo já não existia um lugar seguro para viver. $\mathrm{O}$ espectáculo inicia-se com testemunhos de crianças acerca do conflito sírio, sendo que de repente a luz sobe sobre a cena distinguindo um apartamento em ruínas e uma reprodução da própria teia de iluminação do teatro caída em desequilíbrio, destruída. Uma explosão. Há pó no ar e pedras no chão. Ao fundo, no maple carmesim um homem olha o vazio, um frigorífico destruído e um corpo em espasmos entre cobertores rasgados e colchões sujos. Surgem vultos, o ambiente é pesado, apenas interrompido pelo barulho ritmado de pedras atiradas para o chão por um indivíduo. A imagem é de um apartamento-abrigo em Alepo esventrado por ciclos de violência e silêncio dramático, pessoas deambulam pelos escombros, cambaleantes e assustadas guiadas pela luz de uma lanterna e tropeçando em corpos amontoados como objectos descartáveis. No meio deste ambiente um casal tenta abraçar-se, homens carregam pedras em alguidares e mulheres lavam o cabelo simbolizando toda a normalidade, dignidade e controlo que resta sobre o corpo. Os bailarinos atiram-se ao chão, coberto de pedras, até que Bruno Alves, um dos bailarinos, agarrando num balde cheio de pedras, o despeja sobre si como se o tecto desabasse, pedras estas que são recolhidas posteriormente por Bruno Alexandre que as utiliza como material de reconstrução da cidade. A música retira-se para o fundo, os destroços e as acções permanecem e o espectáculo termina como se voltasse ao início, não procurando uma resolução, mas indicando que o flagelo continuará.

Já o espectáculo Eu Sou Mediterrâneo subiu à cena a 2 de Junho de 2016 no Teatro Turim, em Benfica (Lisboa), passando por uma abordagem ao fenómeno do Jihadismo Global e da Guerra Civil Síria. Com encenação de Mónica Gomes e interpretação de Mónica Gomes, Anabela Pires, Margarida Camacho, Márcio Piósi, Filipe Lopes, Liane Bravo e Sofia Assis, o espectáculo tem como temas centrais os conceitos de "Jihadismo Global", "violência" e "banalidade do mal", procurando 
problematizar a relação entre guerra, política, violência e poder. O espectáculo tem início com uma voz-off que evoca uma referência à morte e à guerra. Segue-se a entrada de $\mathrm{O}$ Coro, uma figura hermafrodita que personifica a liderança enquanto voz do poder acompanhado pela figura da Morte, ao centro, carregando sacas de sarapilheira que empilha no lado esquerdo da cena formando uma trincheira. Durante o transporte das sacas os corpos que as transportavam caem mortos em tiroteio. A figura do Coro assume a rigidez de uma placa que também segura entre as mãos. A placa, composta por seis setas de direção permite situar a ação: "Museu Vivo Guerra Síria”, "Rádio Medo FM" e “Drogaria D. Intolerância”, “O Terrorista - Serviços Aéreos", “Hospedaria Mediterrâneo" e "FOME Snack-bar”. Abre a luz para o lado direito do palco e vislumbra-se uma figura feminina, a Louca, em cima de um pedestal, de punhos cerrados em posição estátua que comenta a ação e narra o início da história de Hasan Al-Phortugali, um soldado jihadista que desertou. O soldado Hasan irrompe então pela cena acompanhado da figura da Morte e continua a narrar a história da sua chegada à guerra na relação com o colega Abdul, um soldado morto (personagem fantasma) que também ingressou as fileiras. A Louca volta a intervir trazendo à discussão a "Pedra de Meca" e o soldado segue a narração, falando agora de Zhaida, uma mulher com quem se cruzou na Turquia e que o levou a desertar, até que a Louca volta a intervir para comentar o conflito na Síria, o que o leva a narrar a história de Razi, um menino palestiniano que foi morto na Faixa de Gaza e cujos destroços humanos foram projectados para Israel, sendo que todos os meses Aziza, a mãe de Razi, deslocava-se a Israel para recolher partes dos destroços da criança para poder realizar um funeral. A Louca intervém novamente questionando o modo como um corpo morto se pode transformar num cadáver histórico. A acção volta-se novamente para o soldado que, agora enforcado em cima do banco, está morto. Há um blackout e tem início uma partitura sonora onde os vários intérpretes vociferam sons de guerra, como se fossem crianças: uma hélice de helicóptero, sons de granadas, alguém que grita ao longe, um corpo que se move no espaço, uma respiração ofegante... Faz-se silêncio. A Louca desloca-se para junto da placa de direções assumindo a posição do Coro. Os corpos começam a dançar. As mulheres juntam-se numa reza. Há um corpo que se autoflagela, um outro que oprime e se liberta. Ao longo da partitura é projetado um vídeo evocando o fascínio mediático pela performance da violência associada à figura do terrorista e do refugiado. Durante esta partitura, a actriz que interpreta a figura do soldado, despe o colete à prova de balas assumindo-se enquanto o Homem, abandonando o papel que representava e, no centro do palco, apela ao combate à banalidade do mal. 


\section{Mujahidins, elefantes e fantasmas}

A memória apresenta-se como matéria fundamental de qualquer criação cénica, seja a memória associada à técnica, ao modo de fazer, a um determinado conhecimento específico, ou até a memória do performer, interpretada e expressa pelo seu corpo (Zili \& Santos, 2015). A própria relação entre a memória, o corpo no teatro e o corpo no quotidiano apresenta um percurso histórico reconhecido através de Constantin Stanislavski, que, no final do séc. XIX e inspirado pela psicologia experimental de Théodule Ribot, recorre à memória das emoções como parte do seu sistema de atuação que procurava, através da representação motora das experiências emocionais vividas, criar uma nova sistematização para as acções físicas do intérprete (Lopes, 2009). A partir de 1920, o Actors Studio, um conjunto de artistas de Nova Iorque, apropriam o sistema de atuação de Stanislavski e criam o conhecido "método de stanislavski", caracterizado por um enfatismo na memória emocional como método de interpretação para o actor (Lopes, 2009). Também, a partir dos anos 1960, num período marcado por revoluções políticas e novos movimentos artísticos, o teatro de Grotovski, Peter Brook e Eugénio Barba apropriam a memória como instrumento para trabalhar e pensar o corpo (Lopes, 2009). Barba coloca o foco do seu trabalho na relação do corpo com a experiência vivida, uma vez que, ao propor o reconhecimento de uma organização básica do corpo do performer entendida como pré-expressiva, ou seja, entendida num conjunto pré-cultural de reacções fisiológicas universais, demonstra-nos como a partitura física é guiada pela nossa memória (Barba, 1995). O corpo é, assim, o lugar da memória do intérprete que, no trabalho com os seus arquivos, encontra formas de materializar o que sente daquilo que recorda.

A performance cénica e o corpo entendido enquanto arquivo surgem, neste contexto, como um lugar que permite evocar a memória dos acontecimentos. Parte-se da premissa de que o estudo da relação entre o corpo, memória e performance nos revela caminhos alternativos, desvios, micro-políticas e acções de resistência face ao mundo social, à arte e ao próprio corpo, na contemporaneidade. Neste sentido, a aproximação entre os estudos da memória e a performance cénica trazem algumas questões relevantes: como pensar a memória na performance cénica quando relacionada com corpos que representam momentos históricos que não aqueles em que as coreografias/encenações foram criadas? O que significa reconstruir um acontecimento? De que modo a memória na performance se pode constituir enquanto micro-resistência? Trata-se de um questionamento da performance cénica enquanto expressão estética que estabelece uma relação com o tempo e o espaço (Cerbino, 2009). E que tempo é este? 
No caso das performances em análise, este tempo é trabalhado como um tempo imobilizado, um tempo que anseia por um desejo trágico de praticar a suspensão (Prinzac, 2005). Fala-se aqui no tempo do drama social, demarcando-se entre o princípio e o fim, preso numa temporalidade que demora. Refere o bailarino André de Campos a respeito desta suspensão da temporalidade no espectáculo Antes que matem os elefantes:

Aquele espectáculo acho que podia começar em qualquer sítio do espectáculo. Por acaso é aquele o início, mas eu acho que podia até começar pelo fim ou começar pelo meio...De repente, alguém abre uma janela e vê aquilo (...). No meu caso eu fiz muita pesquisa antes da peça. Não só pelo que acontece na Síria, mas por várias balizas temporais em que isto aconteceu no mundo, em que houve um conflito, num determinado território, e o grupo de gente viu-se forçado a sair daquele país porque já não havia país. Primeiramente fui mais por aí porque eu quis saber porque é que isto acontece, ou de que maneira é que na Síria é diferente, ou o que é que faz com que aquilo aconteça agora, ou se aquilo é também consequência dos outros conflitos que houve, e fui por aí. (A. de Campos, comunicação pessoal, 9 de Agosto, 2016)

O tempo imobilizado permite também a sobreposição de diferentes tempos sociais, históricos e individuais advindos das noções e necessidades espácio-temporais dos intérpretes e coreógrafa, acentuando ainda mais o carácter liminar da temporalidade definida por Roriz:

Uma coisa que já me perguntaram era se aquilo era mesmo uma hora e cinquenta, aquele espectáculo se era aquele tempo. E eu acho que não, aquilo é muito mais tempo. (...) Há espectáculos que eu faço que passou um dia inteiro. (...) Há outros que eu faço que é naquela hora, é o que se passou naquela hora, é aquela hora mesmo real. E aqui eu acho que não (...). Mas isto depende da cabeça de cada um. Pronto, eu não digo que sejam anos, mas realmente não é um período, não é aquele período que se vê, não é um período real. (O. Roriz, comunicação pessoal, 26 de Julho, 2016)

A concepção do tempo dialoga aqui com a noção de tempo morto, um tempo suspenso caracterizado pela liminaridade que é assumido logo no início do processo social do drama estético - a voz-off das crianças que dá abertura ao espectáculo com uma duração de 7 minutos ou a música que só tem início 20 minutos depois do espectáculo começar - e que convoca uma proposição política. Este tempo morto é um tempo simbólico que procura apelar a uma mudança, uma vez que sem a morte não existiria renovação e, neste sentido, Roriz, ao introduzir uma temporalidade que dialoga com a morte, apela a uma necessidade de agência face à própria suspensão temporal de um conflito que se vê arrastado desde 2011 e afigura enquanto 
temática primordial do seu drama estético. Destaque-se ainda o testemunho do bailarino Francisco Rolo: "Não é porque as pessoas se sentam no teatro que aquilo vai começar. Aquilo está a acontecer e as pessoas estão lá a ver, chegam àquela altura e começam a ver" (F. Rolo, comunicação pessoal, 9 de Agosto, 2016).

É possível compreender como o tempo imobilizado surge como uma estratégia cénica para sustentar uma dramaturgia que tem por base o drama social e que procura no real uma forma de relação com o traumático (Fradique, 2016), ${ }^{2}$ tal como também nos evidencia a coreógrafa:

Imaginei uma câmara, não sei...Qualquer coisa deu-me um tempo diferente realmente, não tão manipulado. Quer dizer, ele é completamente manipulado, mas não é tão manipulado quanto isso, por isso é que o espectador fica ali um bocado: “Ai, ai, isto desemburra ou não desemburra? Desemburra." , quer dizer, está ali, é aquilo e não há música e pronto, levas com aquilo. Portanto, há ali algo de um tempo real em certos momentos, não em todos claro, que eu acho que para mim é fulcral para a construção daquele espectáculo e aquilo que eu tenho de passar para o público ou dar hipótese do público poder pensar. (O. Roriz, comunicação pessoal, 26 de Julho, 2016)

O real toma aqui a forma de espaço liminar onde a marginalidade social, cultural ou física inverte a ordem, transformando-se num instrumento simbólico de renovação (Fradique, 2016). Trata-se de uma manipulação do tempo como forma de afirmação do real enquanto suporte para chamar à cena os dramas sociais do indivíduo moderno (Fradique, 2016): "um real que pode surgir ainda enquanto registo documental que testemunha uma realidade cuja visibilidade dada pela cena adquire um valor político que se torna suporte estético" (Fradique, 2016, p. 136).

Este real é aquilo a que Teresa Fradique, parafraseando Helga Frinter, denomina por um "real imanente", remetendo para a dor física e exaustão enquanto formas de autenticação e fundamento da acção performativa (Fradique, 2016), o que, por sua vez, já havia sido evidenciado por Artaud, ${ }^{3}$ em 1948, com a noção de "corpo sem órgãos" (Deleuze \& Guattari, 1997). Olga Roriz pretendeu, deste modo, estabelecer a relação com o real através de uma violência sobre os corpos e de um tempo ritual, estendido, imobilizado e, em simultâneo, suspenso que se perde, nas palavras de Prinzac, numa "espacialização" (Prinzac, 2005).

Esta imobilização do tempo também se encontra presente no espectáculo $E u$ Sou Mediterrâneo, evidenciando-se, tal como nos destaca a encenadora Mónica Gomes, através de uma continuidade entre tempo e matéria: "Existe, ainda, um ban$\mathrm{co}$, onde o soldado se senta e que se torna num marco temporal ao remeter para uma ideia de imobilidade, de alguém que está à espera ou de qualquer coisa que está em espera" (Gomes, 2016, p. 53). 
O banco assume a expressão da temporalidade ao longo do espectáculo, remetendo também para um tempo em suspenso, ou seja, um tempo que não acaba e que é liminar (Van Gennep, 1978) e tal como nos destaca a antropóloga Paula Godinho: "o limiar é uma soleira, separa o que está fora do que já é interior. É uma passagem em que nos demoramos, num tempo-espaço criativo, entre duas margens" (Godinho, 2014a, p. 12).

Este tempo liminar está presente no banco enquanto marcador espácio-temporal que representa algo pelo qual o soldado está sempre à espera mas que nunca vem, encontra-se também associado a um ritual de passagem (Van Gennep, 1978) que marca o final do drama estético - a morte do soldado - , uma vez que é o banco que lhe é retirado debaixo dos pés aquando do seu enforcamento. Mas, se durante todo o espectáculo, o tempo é um tempo imobilizado, objectificado no banco de cena, durante a partitura de dança dá-se uma mudança temporal, onde o aspecto ritualizado do tempo se insurge:

Após a segunda morte do soldado existe um blackout e uma partitura sonora, na qual são reproduzidos sons associados à ideia de guerra. Estes sons reflectem parte do universo interior das personagens, mas também correspondem ao já referido renascimento do próprio espectáculo, à semelhança do recém-nascido que chora para receber o oxigénio que lhe dá a vida. Este renascimento está associado a uma mudança temporal, sublinhada no discurso da Louca - “Este é o tribunal dos tempos. E o tempo urge. Urge. O tempo."; mas também pelas metamorfoses do soldado, do Coro e da própria figura da Louca. Os "tempos" aludem às vidas humanas, que têm uma duração, e o "tribunal" apela ao auto-julgamento no sentido da auto-correcção, da reflexão. O recém-nascido espectáculo, tal como o processo natural da vida, parte da morte e segue o fluxo normal: nascimento, vida e morte novamente. Se o nascimento corresponde ao momento da partitura sonora, a vida corresponde à partitura de dança (...), uma partitura que procura expressar a luta da vida que, mais uma vez, culmina na morte, reconhecendo o ciclo natural da vida que assenta no constante renascimento. (Gomes, 2016, p. 52)

A partitura de dança marca o renascimento do espectáculo e uma nova consciência face à componente político-ideológica e ao processo social do drama estético. Evidenciando-se como uma fase de "margem" (Van Gennep, 1978), tal como é entendida por Van Gennep, a partitura é marcada por uma poderosa "communitas", enquanto única fase que agrupa todas as personagens em cena, bem como por uma "anti-estrutura" (Turner, 1974), momento em que os estatutos sociais dos personagens se invertem e a separação actor/personagem se confunde. É também definida por um tempo sagrado, pois é durante a partitura de dança que se dá o momento do sacrifício e da reza colectiva por parte das mulheres. Após a partitura dá-se a fase "pós-liminar" (Van Gennep, 1978), ou seja, a transformação do espectáculo e dos 
personagens, um momento de incorporação do renascido espectáculo com uma nova consciência. Neste sentido, a partitura evidencia uma separação do tempo e das fases da vida particularmente demarcada: entre nascimento, vida, morte e renascimento.

Já a actriz Anabela Pires, intérprete do personagem Louca, dá-nos ainda conta da sua dificuldade em controlar o tempo:

O tempo foi um aspecto pelo qual me debati inúmeras vezes, pois senti uma certa dificuldade em calcular, por exemplo, quanto tempo (duração) é que poderia estar a rir ou qual o tempo (ritmo) certo para dizer determinada sequência de palavras. (A. Pires, comunicação pessoal, 05 Agosto, 2016)

A ideia de que existe um tempo certo para realizar uma determinada acção apresenta analogia com uma necessidade da sociedade em controlar o tempo, medindo-o em momentos por si determinados e circunscritos, cuja expressão fundamental é assumida pelos calendários que procuram fixar um tempo sem interrupções, sem tempo morto (Godinho, 2014a). Contrariamente ao tempo que marca o personagem Soldado que encontrava no tempo morto e na imobilização temporal uma estratégia de expressar o seu estado de espírito resignado, uma posição face ao conflito e um método de colocação do real em cena, a Louca representa a escrita da História e a construção memorial dominante cuja temporalidade é socialmente e fortemente demarcada e construída (Godinho, 2014a). Neste sentido, a linha espácio-temporal da Louca remete-nos para a noção de lugar de memória, no sentido em que remete para uma suspensão do presente e uma manipulação da história e da memória como referenciais identitários (Peralta, 2007).

A opção pelas diversas temporalidades em ambos os espectáculos dialoga com um entendimento do espaço cénico enquanto "lugar de memória", tal como proposto por Nora, e que evidencia uma certa instrumentalização do tempo e da memória, uma vez que "nenhum lugar de memória escapa aos seus arabescos fundadores" (Nora, 1993, p. 22). Apesar de uma certa instrumentalização, continuam a emergir ligados a si acontecimentos e datas-chaves que deambulam entre o passado e o presente "sem se fixarem em tempo algum" (Peralta, 2014, p. 229), o que nos remeterá mais adiante ao conceito de "matérias-fantasma" de Avery Gordon (Gordon, 1997). Por este motivo o espaço cénico pode ser entendido como um espaço liminar, sendo "the betwixt and between" (Schechner, 1986, p. 7) e, neste sentido, dá lugar a uma "fronteira, a terra de ninguém, que foi zonal e se tornou linear" (Godinho, 2014a, p. 12). Esta é uma fronteira perigosa, sendo um "espaço marginal, periférico, descontrolado - porque fora de controlo pelos centros - torna-se zona de refúgio" (Godinho, 2014a, p. 12) e um lugar de 
resistência. É este uma soleira que se situa entre a memória e a história, entre as "memórias fortes" e as "memórias fracas" (Traverso, 2012). E esta fronteira, este espaço liminar é também o lugar do corpo, da dança-teatro e da memória enquanto territórios convergentes, uma vez que o corpo possibilita minimizar distâncias espácio-temporais, compartilhar mundos e actualizar o tempo através do gesto (Porpino, 2010).

A primeira aproximação à temática da memória é apresentada através do estudo de caso Antes que matem os elefantes e a partir das experiências dos bailarinos face ao que Porpino, parafraseando Le Breton, denominou por "memória afectiva", ou seja, uma memória que permite a criação de "identidades provisórias" que, simultaneamente, se confundem e distinguem com o próprio intérprete (Porpino, 2010):

Há certos momentos em que não é bem o André que está ali, mas é fruto de um processo muito íntimo, muito intenso, de todo o trabalho que foi feito em estúdio e de toda a pesquisa que foi feita. (...) Acho que nós passamos por vários momentos, por vários rostos, por várias vozes. Se calhar também daí as diferentes vozes que aparecem no início do espectáculo. (A. de Campos, comunicação pessoal, 9 de Agosto, 2016)

Se entendermos o arquivo como um depósito de documentos ou um sistema que permite a elaboração dos discursos (Dias, 2015), o corpo é possível de ser compreendido enquanto arquivo e lugar de processos de materialização de identidades, que, no caso de André de Campos, assume várias vozes, entre a dominação e a subalternidade, uma vez que este tanto interpreta uma figura dominante quanto subalterna (Scott, 2000). O arquivo corresponde à história individual, encontrando-se nas margens do corpo, pelo que o arquivamento do eu é uma forma de construção de si próprio e um mecanismo de resistência, uma vez que, se considerarmos como destaca Dias, um prisioneiro que escreve um diário, compreendemos que o modo como este olha para a sua própria vida transforma a escrita a partir do momento em que sabe que o diário será lido (Dias, 2015).

Eu sempre vi aquele sítio como um sítio que já tinha sido algo muito bom antes, ou seja, a minha relação com aquele sítio era sempre um bocadinho dali para trás e nunca dali para a frente porque eu sempre achei que dali para a frente existiria o nada e o que eu queria era um bocadinho voltar para trás, como se calhar muitas pessoas que estão naquela situação querem, não é? É um bocadinho voltar atrás no tempo. (F. Rolo, comunicação pessoal, 9 de Agosto, 2016)

\footnotetext{
“Apesar de habitarmos o mesmo espaço, todos nós tínhamos passados diferentes e tempos diferentes e, em termos de processo, todos fizemos sete escolhas diferentes sobre" (A. de Campos, comunicação pessoal, 9 de Agosto, 2016).
} 
Francisco Rolo fala-nos assim de um corpo que arquiva uma versão memorial marcada pela nostalgia. O corpo, tal como denuncia o discurso do bailarino é um arquivo de distintas temporalidades onde o presente dialoga com o passado e com o futuro. Deste modo, o corpo-arquivo constitui-se como uma memória criada pelo conjunto de sistemas sensório-motores organizados pelo hábito - porções de comportamento restaurado (Schechner, 2006) - , evidenciando como o corpo social determina a percepção que temos do corpo físico (Douglas, 1978) e sendo uma memória presente para onde confluem diferentes tempos, tal como evidenciou o bailarino André de Campos.

O corpo dos bailarinos/intérpretes ao recorrer aos seus arquivos transforma-se numa forma de materialização da memória, sendo que estes arquivos não correspondem apenas às memórias pessoais, mas também ao "filme-arquivo" enquanto fonte de pesquisa dos intérpretes e parte estruturante das memórias que estes assimilaram do conflito sírio:

Depois também houve alguns documentários que nos permitiram...Pelo menos para mim foi a primeira vez...Nós vimos também alguns que foi daquele site que é o "Vice", que costuma fazer alguns documentários diferentes no sentido em que...Neste caso vimos vários jornalistas que estavam a acompanhar principalmente a frente dos rebeldes e, pelo menos para mim, foi a primeira vez que tive um bocadinho do que é estar mesmo ali, tanto que o jornalista estava mesmo ao lado dos combatentes. (...) Porque de repente vê-se uma pessoa que cai, fica no chão e, de repente, ouve-se um estrondo gigante e prédios a cair, mas há momentos em que aquilo parece que quase não é real porque não há uma ligação directa entre...Não se vê tudo, não é? Vê-se sempre um lado. (F. Rolo, comunicação pessoal, 9 de Agosto, 2016)

“Sim, não era um filme, não era...Quer dizer, nós vimos mesmo pessoas a morrer, cadáveres, e não é um filme "(A. de Campos, comunicação pessoal, 9 de Agosto, 2016). “Sim e muitas das fotografias também que a Olga nos foi mostrando. Às vezes uma fotografia dava para explorar imensa coisa" (B. Dias, comunicação pessoal, 9 de Agosto, 2016).

Os filmes/documentários abordavam as histórias do conflito sírio, manejando a violência e a crueldade que o passado/presente evocam e transformando-se, assim, em "filmes-arquivo" (Souza, 2008). O arquivo do corpo dos bailarinos de Roriz é, deste modo, composto em grande parte por estes "filmes-arquivo" que trabalham e produzem os acontecimentos e falam de uma experiência traumática, insurgindo-se como um documento histórico socialmente construído e fonte de pesquisa histórica, do imaginário e da memória social dos intérpretes (Souza, 2008). É a partir da mobilização dos "filmes-arquivo" como referenciais 
mnemónicos que aludem a uma "memória forte", ou seja, "memórias oficiais, alimentadas pelas instituições, ou seja, os Estados" (Traverso, 2012, p. 71) que os bailarinos, através da dança, pretendem questionar a história. O facto de Francisco Rolo procurar ver documentários "diferentes" prende-se com uma tentativa de contestar as narrativas dominantes em torno do conflito sírio, procurando pelas "memórias fracas" e por um conhecimento alternativo que pudesse estruturar a sua acção em cena (Traverso, 2012).

Ainda, os corpos na sua relação com os "filmes-arquivo" permitem levantar "espectros" e "matérias-fantasma" que integram o corpo dos intérpretes como forma de relação com o traumático (Gordon, 1997):

Os gritos e os clamores, os silêncios, a densidade da história da nação, as justificativas ideológicas, as forças geopolíticas, a capacidade criativa de longa data para o terror doméstico (...), a assustadora resistência política, etc. - não se somam o suficiente. Eles podem ser isolados e colocados a nu, e podem ser colocados num ímpeto político de exposição, mas parece que, nesse mesmo ato, os fantasmas retornam, exigindo um tipo diferente de conhecimento, um tipo de reconhecimento diferente. (Gordon, 1997, p. 64)

O irromper dos "fantasmas" na construção da "identidade provisória" (Porpino, 2010) dos bailarinos altera a experiência de estar no tempo e a "maneira como separamos o passado, o presente e o futuro" (Gordon, 1997, p. xvi). Mas esta relação com as "matérias-fantasma" é tanto ou mais relevante no universo feminino: "As mulheres estão mais numa zona de memória, de sofrimento, de apaziguamento também" (O. Roriz, comunicação pessoal, 26 de Julho, 2016).

Portanto, o corpo muitas vezes entrava numa tensão tão grande nesta contraposição de... Lá está, da memória, do querer voltar ao passado, tentar recuperar alguma coisa que quero de novo, mas também da saturação e da frustração de ter ficado naquele sítio. E o corpo muitas vezes...Lá está, coloca-se de uma forma um pouco mais passiva, mais...Ou sentada, ou só olhar, ou de outra forma que era um movimento mais rápido, mais acelerado, mas estava sempre um bocadinho à base dessa contraposição da insistência no espaço e no voltar atrás...Dessa revolta, às vezes dessa saudade...Acabava por ser uma saudade também. (B. Dias, comunicação pessoal, 9 de Agosto, 2016)

A referência ao trauma associado às perdas não surge apenas como uma referência a uma instância temporal, a história do conflito sírio encontra-se transformada no corpo dos intérpretes, e, neste sentido, não é uma memória que traz de volta o passado daquele determinado momento ou período, mas um lugar de temporalidades diversas, no qual o trauma é apropriado enquanto acção de transformação e libertação. A 
própria violência exercida sobre o corpo como dispositivo de expressar o trauma é uma forma de explorar as possibilidades do corpo e testar a resistência à dor, não numa referência aos limites do corpo das bailarinas (uma vez que são as mulheres que são indicadas de forma mais explícita pela coreógrafa como portadoras de uma memória do trauma), mas de todos os corpos envolvidos no conflito, pelo que não se trata de um corpo passivo, um mero depósito, mas sim um corpo resistente revoltado contra o biopoder e o disciplinamento (Foucault, 1987; Furtado, 2012).

É possível compreender o corpo no espectáculo Antes que matem os elefantes como um lugar que arquiva uma "versão provisória" do conflito sírio que, marcado pelas "versões fortes" e "versões fracas" (Traverso, 2012), ${ }_{4}^{4}$ procura contestar as práticas memoriais hegemónicas através da libertação de "fantasmas" (Gordon, 1997), assumindo-se como micro-resistência.

Já no espectáculo Eu Sou Mediterrâneo também é evocada uma "memória afectiva" que estrutura a "identidade provisória" dos intérpretes (Porpino, 2010). A encenadora/actriz Mónica Gomes remete-nos para o método de Stanislavski a respeito da sua interpretação no personagem Coro durante a partitura de dança:

Em termos de emoções vou buscar à minha experiência, vou buscar ao sentimento pessoal, nomeadamente o medo eu vou buscar ao sentimento de perda. Vou buscar a memórias de perda e ajuda-me a transmitir melhor o medo. Por isso há vezes acontece eu chorar, é algo que pode acontecer, pelo facto de estar a trabalhar com emoç̃os que me são muito próximas. (...) Eu acho que quando nós tentamos reproduzir as memórias traumáticas dos outros acaba sempre por ser muito injusto e não sabemos bem o que estamos a fazer porque não podemos assumir que podemos estar na pele do outro. Nós não podemos estar na pele do outro, nós podemos estar na nossa pele e tentar imaginar um pouco do que é que poderíamos sentir se fossemos o outro. E para isso recorremos às nossas emoções piores, a momentos da nossa vida mais trágicos e tentar colar isso com o que poderá ser o sentimento. (M. Gomes, comunicação pessoal, 14 de Agosto de 2016)

O corpo transforma-se, deste modo, num território bio-cultural de memória que é constantemente actualizado pela própria dança/interpretação, uma vez que ao dançar/interpretar permite mobilizar o passado, criar um presente e projectar um futuro (Porpino, 2010). A própria relação entre dança e memória é reforçada a partir do momento em que a dança acarreta em si uma memória social histórica representativa dos povos que a criaram, estando imbuída em sentidos e significados relacionados com a cultura que a originou (Porpino, 2010). Para além disto, a dança insurge-se também como uma forma de reconstruir memórias de grupos sociais (Félix dos Santos et al., 2016). O corpo é, deste modo, um texto vivo onde se inscreve a memória, sendo através do gesto que essa memória é exteriorizada chamando ao presente um tempo passado: 
Quando eu faço com as mãos pelo corpo com o grito que é um bocado a libertação. É como se fosse uma limpeza, começando no peito até lá abaixo, portanto, esfrego as mãos no corpo limpando-o até empurrar o Filipe que é o "mau da fita" na dança, que eu acho que representa não só o homem todo, mas a tradição. As pessoas que estão muito agarradas aos costumes, à tradição, e não se libertam disso. Eu acho que, não é considerar que o homem, o líder islâmico, é mau, mas a tradição. Ser agarrado ao passado e viver no passado. Então aquilo, quando eu o empurro, é um "vou-me libertar do passado", a libertação do passado para continuar em frente. (M. Camacho, comunicação pessoal, 12 de Julho, 2016)

A intérprete/bailarina Margarida Camacho ao descrever-nos o seu desempenho no solo da partitura de dança em Eu Sou Mediterrâneo, fala-nos precisamente do tal tempo marcado pela ucronia, ou seja, "relendo sucessivamente o presente à luz do que poderia ter sido, (...) um tempo de presentismo e de história finalizada, que parece não querer construir para a frente e resgatar possíveis no universo das impossibilidades" (Godinho, 2014b, p. 13). Um tempo que a antropóloga Paula Godinho define como um "tempo pegajoso" que se encontra ligado a um acontecimento ou trauma de um cataclismo (Godinho, 2014b). A intérprete/bailarina procura, deste modo, revoltar-se contra um "mundo sem utopias" (Godinho, 2014b), demonstrando-nos de que forma a dança permite "tocar o fantasma", ou seja, as complexidades do poder, a violência e a esperança, as sombras de nós próprios e da sociedade e o modo como esses "fantasmas" podem tocar a intérprete (Gordon, 1997). Margarida Camacho ao representar os sujeitos silenciados e excluídos da história chama à cena a necessidade de criar uma nova identidade cultural que olhe para o seu passado de forma crítica e permita ter uma perspectiva de futuro (Cedeño, 2010), pois, apesar de representar uma perda ou, neste caso, um caminho não tomado, "o fantasma também representa simultaneamente uma possibilidade futura, uma esperança" (Gordon, 1997, p. 64).

A própria noção de incorporação - embodiment - declara que a memória é um processo corporal e emocional que se enraíza em práticas e hábitos quotidianos. Neste sentido, a "memória-hábito", enquanto passado que se encontra sedimentado no corpo, apresenta-se como fundamental para o entendimento das histórias dos grupos sociais subalternos (Espinosa Arango, 2007), sendo que esta "memória-hábito" é uma memória que se encontra presente em todas as performances enquanto acções que se constroem a partir de comportamentos previamente experienciados ou, como designado por Schechner, "porções de comportamento restaurado" (Schechner, 2006, p. 4) que se apresentam como espaço privilegiado para a compreensão da memória do trauma. A actriz/bailarina demonstra-nos também de que modo a "memória afectiva" (Porpino, 2010) enquanto "memória-hábito" guiou a sua interpretação: 
Em relação ao que senti na dança, as emoções que fui buscar, (...) fui buscar à minha vida. Passei por momentos de medo, por momentos de depressão. De não me puder defender em relação aos homens. Sofri muito na mão de um Homem, calada. Mas um dia basta. O nosso corpo é nosso, é um templo, temos de o defender. Muita lágrima rolou no meu rosto, acho que a dança do mediterrâneo ajudou-me a passar algumas mágoas. Em relação às mulheres, somos especiais. Temos de lutar por nós. (M. Camacho, comunicação pessoal, 12 Julho, 2016)

Refere-nos Diana Taylor que o trauma e os seus efeitos pós-traumáticos continuam a manifestar-se corporalmente muito tempo depois do acontecimento que lhe deu origem, regressando e repetindo-se sob a forma de comportamentos e experiências involuntárias (Taylor, 2000). A intérprete Margarida Camacho demonstra-nos acima que testemunhar o trauma é relembrar algo que se quer esquecido. Foi a partir desta suposição que guiou o seu trabalho, actualizando através do gesto uma "memória fraca", privatizada, de violência contra as mulheres e dominação masculina (Bourdieu, 2002). A manifestação do "fantasma" (Gordon, 1997), o reverter da "memória fraca" em "memória forte" (Traverso, 2012) e a exposição da "assombração", permitiu-lhe reivindicar por um futuro alternativo, uma vez que, como propõe Gordon, "assombrar aterroriza, mas dá-nos algo que temos de tentar por nós mesmos" (Gordon, 1997, pp. 134-135). Mais do que nos falar num passado, a intérprete fala-nos num futuro, pois ainda que a performance não seja uma acção involuntária, partilha com o trauma essa restauração de comportamentos experienciados previamente evocados por Schechner (1986) e, neste sentido, surge muitas vezes como transmissora de memórias traumáticas permitindo também uma ressignificação das mesmas para a construção de novos futuros. A performance é, deste modo, um agente transmissor de uma memória social que extrai e transforma imagens culturais que advêm de um determinado arquivo colectivo (Taylor, 2000).

Esta noção toma especial relevância se considerarmos as influências da "dança-teatro" de Pina Bausch tanto no espectáculo Antes que matem os elefantes, de Olga Roriz, como em Eu Sou Mediterrâneo, de Mónica Gomes. Pina Bausch foi uma coreógrafa alemã, que por volta de 1980, fundindo a dança moderna alemã com a dança pós-moderna americana, começa a basear o seu trabalho nas histórias de vida dos bailarinos com quem trabalhava, procurando através da codificação dos gestos encontrar uma memória emocional (Garcia, 2012), utilizando a repetição como estratégia de distanciamento da realidade. Destaque-se aqui o testemunho da intérprete/bailarina Margarida Camacho a respeito da influência da tanztheater bauscheana na sua performance em Eu Sou Mediterrâneo: 
É assim, a dança da Pina Bausch ensinou-me a olhar em volta, em vez de falar, escutar e olhar. Porque nós encontramos o gesto numa pessoa que está simplesmente a comer ao nosso lado ou quando a pessoa está no caos da sua vida e quer sair e não consegue, há um gesto associado. Então, é olhar, observar, estudar o movimento que a pessoa está a fazer e depois pensar em como o transmitir na dança. Os principais fundamentos da Pina Bausch que utilizo... É... Ela agarrava muito na vida dos bailarinos para a "fazer" na dança. A experiência pessoal... (...), nós passamos sempre por momentos maus e bons e a dança consegue retirar desses dois coisas boas, gestos bons, e ajuda também a limpar cicatrizes, a fechá-las. E foi isso que a dança fez comigo e vai fazendo, não é? Esquecer um bocado o passado, fechando as feridas. Nós falhamos sempre, como acertamos em coisas. Agarrei em muitas falhas minhas, tentei fechar as feridas, esquecê-las e transmiti-las na dança. (M. Camacho, comunicação pessoal, 12 de Julho, 2016)

Portanto, ela [Pina Bausch] além de ir buscar movimentos a situações do quotidiano, ir também à sociedade, improvisação, caos de grupo, o corpo é usado para estimular a nostalgia, tem também técnica do ballet, usando-a sim de uma forma crítica, usa movimentos repetitivos e estranhos ... O que é eu vejo nisso? O mundo demora muito a perceber hoje em dia, nós somos um povo...não é todo, mas muitos de nós não têm cultura e a nossa mente funciona pela repetição. Então os movimentos que vou buscar à Pina Bausch são repetitivos e muito mecanizados. (M. Camacho, comunicação pessoal, 12 Julho, 2016)

Margarida Camacho demonstra-nos como o corpo é uma memória viva em constante recriação que permite uma ressignificação de memórias traumáticas. O corpo encontra-se num momento presente, pelo que a memória corporal é sempre um acontecimento do presente e só pode ser compreendida a partir do presente, até porque a memória corporal é uma memória de sensações e estas, como defende Rosely Conz, só podem ser lembradas no momento em que são sentidas (Conz, 2012).

Dançar/interpretar entre o corpo e o lugar de memória permitido pelo corpo enquanto arquivo é atender a uma "política do chão" e lidar com "matérias-fantasma" que brotam do corpo na sua relação com o chão e com a memória (Gordon, 1997; Lecpecki, 2013). Se como salientei no segundo capítulo, as matérias-fantasma são todos os "corpos impropriamente enterrados da história" (Lecpecki, 2013, p. 114), como interpretar o corpo-arquivo enquanto repositório dessas "matérias-fantasma" que, tal como o "corpo arquivo" só podem ser compreendidas a partir do presente?

O corpo do intérprete-personagem Mónica Gomes/Soldado Hasan no espectáculo Eu Sou Mediterrâneo surge como dispositivo para arquivar uma determinada memória da experiência jihadista na guerra, presente na sua gestualidade 
enquanto "porções de comportamento restaurado" (Schechner, 2006), mas também através do seu discurso:

O Razi morreu. Quem é o Razi? Ah, não te contei? Conheci-o quando o meu líder me mandou a mim e ao Abdul de espias para a faixa de Gaza. (...) Como é que morreu? Olha, mal a manhã despertou com as primeiras orações, estava o puto na escola e zás! Levou com um projéctil em cima. Pois, não se safou. O funeral? Nós não fizemos funeral, tio, ele com embate foi logo projectado para Israel. É, passou a muralha e tudo. E como a terra é santa deixámo-lo lá. Se parecia em paz? Não, tio, parecia morto. Equando lá fui o mês passado já não o vi. Mas encontrei lá a mãe dele de pá na mão. Parece que consegue fugir sempre nalguns meses para vir à procura de um osso do Razi para levar para o campo de refugiados. (...) Andava a evitar mas, ontem, até lhe perguntei: Ó ti Aziza se já tem o occipital e o fémur porque é cá volta em Fevereiro? E ela respondeu-me "Quando eles me o levaram, levaram-no inteiro, por isso venho cá todos os meses. Quero que regresse como foi. (Gomes, 2016, p. 107)

O discurso do personagem soldado Hasan, interpretado por Mónica Gomes, ao longo de todo o espectáculo procura problematizar a versão jihadista enquanto versão reprimida e proibida pelas instâncias políticas ocidentais, apresentando-se sob uma forma discursiva que procura humanizar o sujeito jihadista e banalizar as suas acções. Irrompendo nas sociedades ocidentais enquanto uma "versão fraca", ou seja, versões dos acontecimentos "subterrâneas, escondidas ou interditas" (Traverso, 2012, p. 71), e opondo-se às versões oficiais alimentadas pelos Estados ocidentais, a versão jihadista foi atirada para a clandestinidade e perpetuada como uma versão estigmatizada e criminalizada pelo discurso dominante. Neste sentido, Mónica Gomes, através do discurso do personagem, pretende alertar para o facto de que, tal como nos destaca Enzo Traverso para a questão da memória, a visibilidade e reconhecimento da versão do acontecimento depende "da força de quem a possui" (Traverso, 2012, pp. 71-72) e demonstrar como, através de uma forte pressão por parte dos meios de propaganda jihadista e pela consequente apropriação dos mídia ocidentais na construção de uma versão dos acontecimentos por parte destes grupos insurgentes islâmicos, a versão jihadista passou de periférica, de "versão fraca" a "versão forte" (Traverso, 2012). Também o discurso da personagem Louca como comentário à analepse "A história de Razi e o telefonema do soldado arrependido", procura evidenciar que a própria versão do jihadismo nas sociedades ocidentais encontra-se directamente ligada um conjunto de migrações forçadas que contribuiram para a sua transmutação em "versão forte":

Mas, quando se conquista um estatuto? Quanto será que um cadáver se torna um cadáver histórico? Quantos anos tornam um genocídio romântico? Razi, Razi... Razi, 
Razi, Razi... Não é um cadáver histórico. Não deu à costa na Europa, portões bonitos esses... Bonitos, bonitos, bonitos. (Louca, como citado em Gomes, 2016, p. 116)

Através da crítica à morte do personagem Razi, o rapaz palestiniano que foi morto na Faixa de Gaza, o discurso da Louca pretende trazer à tona a versão dos "desaparecidos" e das "assombrações" (Gordon, 1997), marcados pelas "versões fracas" (Traverso, 2012). Destaque-se a afirmação de Gordon relativamente ao estatuto do "desaparecido":

Desde que nós te fizemos desaparecer, tu não és nada. Enfim, ninguém se lembra de ti. Tu não existes. Uma característica constitutiva aterradora do desaparecimento é que os desaparecidos desapareceram e com eles todos os conhecimentos públicos e oficiais dos mesmos. Há um conhecimento sombrio, com certeza, e, de fato, o desaparecimento aterroriza a população de uma nação em grande parte pela incerteza que um segredo tão divulgado abrange, mas o Estado e seus vários representantes afirmam não saber nada. (Gordon, 1997, pp. 78-79)

$\mathrm{O}$ "fantasma” de Razi surge na comparação e crítica à construção da versão hegemónica do acontecimento presente na criança Aylan enquanto parte de uma "versão forte" que parte de uma apropriação das vítimas do conflito pelo imaginário europeu, transformando-as num elemento constitutivo da própria identidade europeia. Este fenómeno teve origem com o irromper da vítima como sujeito privilegiado do direito da justiça internacional (um fenómeno pós Segunda Guerra Mundial), no qual a vida política depois da morte foi alargada a pessoas comuns e, assim sendo, o cadáver biológico e social insurge-se também enquanto cadáver político (Alonso, 2015), pelo que "en la actualidad es la propia evolución de la sociedad de los vivos la que va utilizando los cuerpos muertos como símbolos de distintas ideas políticas, casi con independencia de la propia trayectoria vital del difunto" (Alonso, 2015, p. 316).

A opção pelo facto da personagem de Razi nunca aparecer no espectáculo surge também como proposição política que tem em vista evidenciar o modo como os desaparecidos perdem a sua identidade social e política, uma vez que não há registos burocráticos, memoriais, funerais ou corpo e, neste sentido, transformam-se num meio de dominação (Gordon, 1997). A expulsão destes "fantasmas" em cena aparece também como um símbolo de que existe uma hipótese na luta pelo passado oprimido, procurando transformar as "versões fracas" numa "versão forte" (Traverso, 2012) com o desígnio de estabelecer um futuro que não apague a versão dos vencidos: 
Após o reconhecimento, o passado oprimido ou o fantasma nos surpreenderá ao reconhecer a sua força animadora. Na verdade, lutar por um passado oprimido é fazer com que este venha vivo como a alavanca para o trabalho do presente: obliterar as fontes e as condições que ligam a violência do que parece terminar com o presente, acabando com essa história e estabelecendo um futuro diferente. (Gordon, 1997, pp. 65-66)

A antropóloga Paula Godinho fala-nos numa "privatização da memória", ou seja, em memórias que não podem ser recordadas em público, e por isso foram "longamente privatizadas, domesticadas, silenciadas, porque perigosas" (Godinho, 2013, p. 204). A ideia de uma privatização de uma determinada versão dos acontecimentos aparece representada no personagem Aziza, a mãe de Razi, que surge como "matéria-fantasma" (Gordon, 1997) portadora de uma memória traumática que representa todas as mães cujos filhos morreram ou desapareceram na guerra ou em consequência desta e cujo "dano infligido ou a perda sofrida por uma violência social feita no passado" (Gordon, 1997, p. xvi) permanece domesticado. O aparecimento de Aziza enquanto "matéria-fantasma", contrariamente ao trauma, implica que algo deve ser feito, é o momento em que "as pessoas que se destinam a ser invisíveis se dão a ver sem qualquer sinal de partida, (...) quando algo diferente, algo diferente de antes, parece que tem de ser feito" (Gordon, 1997, p. xvi). A desprivatização de versões dos acontecimentos, a possibilidade de as tornar públicas, ou seja, o "reconhecimento do fantasma" (Gordon, 1997), como o evocou Avery Gordon, é muitas vezes impossibilitada pela dominação e obscurecida pelos consensos hegemónicos e, neste sentido, as práticas artísticas (refira-se o teatro e a dança) apresentam-se como uma possibilidade na "desprivatização de versões" (Godinho, 2013). Este argumento é nitidamente evidenciado pela encenadora Mónica Gomes em relação ao personagem Louca:

A Louca, do lado direito, excepto durante as suas intervenções, assume uma posição estática, em cima de um pedestal, composto por uma caixa preta semelhante ao pedestais de Museu. O museu que é por excelência o lugar de homenagem à memória, de exposição da História. Esta imagem procura remeter para a ideia de estátua e para a importância da memória e da arte como forma de inscrição na grande História, que no caso da Louca reflete a memória traumática. (Gomes, 2016, p. 53)

Apesar do personagem Louca falar sempre a partir do pedestal, símbolo das "versões fortes" (Traverso, 2012) e da escrita da história, nalguns momentos, entre eles a crítica à história de Razi, o personagem desce do pedestal, tomando a frente do palco, sendo que este assumir da frente do palco marca os momentos em que os "fantasmas irrompem" por entre o discurso memorial reivindicando um lugar para as versões silenciadas na História oficial e um reconhecimento público da " 
assombração" (Gordon, 1997). A par da Louca, também o personagem Coro estabelece uma forte relação com a performance da memória traumática, uma vez que o seu corpo é a reencarnação da própria "assombração" (Gordon, 1997):

O Coro (...) vem dar voz aos mortos e mimetizar momentos passados, assumindo identidades várias, reforçando a importância do registo e da memória. (...) Também por isso o Coro está presente em grande parte do tempo, nem que seja em contra-luz, pois é a sombra e a presença constantes de um passado que ajuda a construir e reconstruir o presente e o futuro. (Gomes, 2016, pp. 46-47)

O Coro é o melhor exemplo de como evocar os "fantasmas" através dos dramas estético-teatrais é dar visibilidade às "versões fracas" (Traverso, 2012), ajudando-nos "a olhar para trás para ter a certeza de que o futuro existe, pois foi por ele que caíram os que hoje aqui lembramos" (Godinho, 2013, p. 205). Desta forma, o discurso do soldado ou a presença da Louca e do Coro não pretendem apenas expressar histórias de "fantasmas", mas consertar erros de representação e "entender as condições em que a memória foi produzida em primeiro lugar, em direção a uma contra-memória, para o futuro" (Gordon, 1997, p. 22). Neste sentido, o espectáculo não só questiona as versões dominantes, como se converte num espaço alternativo para a expressão das "versões dos fracos" de grupos que foram excluídos da história oficial, sendo que aqui as "versões fracas" apresentam uma estreita relação com o "discurso oculto" dos subordinados (Scott, 2000).

\section{Conclusão}

A prática memorial enquanto matéria do fazer artístico surge como um instrumento simbólico de rememoração a partir do corpo (Zili \& Santos, 2015). É a partir do corpo enquanto arquivo e repositório das "versões fracas" em confronto com as "versões fortes" (Traverso, 2012) que os artistas reclamam as memórias silenciadas ou suprimidas da Guerra Civil Síria ou dos seus conflitos e traumas pessoais. Procuram, através da transposição de sentimentos relativos às versões traumáticas de um período marcado pela repressão, guerra e violência, reinterpretar os factos e encontrar um sentido de justiça, ao passo que denunciam a instrumentalização da memória em função de uma história oficial do conflito. Mais do que propor um reconhecimento dos "fantasmas", os artistas pretendem reclamar o seu não esquecimento e partir destes propor uma consciencialização em torno do conflito, pois, o "reconhecimento do assombramento é uma maneira especial de saber o que aconteceu ou está a acontecer" (Gordon, 1997, p. 63). Se o conflito político, a ordem da 
revolução e a desordem da guerra, ou seja, o "drama social" refletido na performance, se descarrega "na sensibilidade de quem o observa com a força de uma epidemia" (Artaud, 1983, p. 22), esta epidemia ou mise-èn-scene do "drama social" é tecida no momento em que o corpo encruzilha as teias da memória com as tramas do esquecimento. Urdida no palco da história, a mise-èn-scene do "drama social sírio" compõe-se a partir de memórias e esquecimentos, sobrepondo o passado ao presente para que se crie um futuro.

Posto isto, torna-se relevante atentar a possíveis linhas de pesquisa futuras que versem sobre o modo como os artistas lidam e tratam esta atraç̧ão pelo real na qual o chão necessita de uma terraplanagem para a criação de um espaço "neutro", um espaço que se torna liso para de seguida se voltar a tornar estriado através da performance cuja potência subjuntiva interage com as "matérias-fantasma", os corpos mal enterrados, os fins que não terminaram e que agora retornam. Falam-se, deste modo, em versões dos acontecimentos que são criadas e têm o corpo dos intérpretes/bailarinos como mediador, memórias individuais e "versões fortes" que se fundem numa performance que é liminar. Não será relevante atender a que técnicas mnemônicas são utilizadas pelos artistas na representação deste real em cena e de que modo? De que forma se cria espaço para uma experiência liminar que envolva tempos reais e irreais? Que procedimentos de criação podem ser estruturantes de uma abordagem artística ao real? De que modo e por que meios os artistas lidam com o chão nas encenações do real? Será "lisa" a interação entre o chão e a história ou entre as memórias pessoais dos artistas e as "versões fortes" da guerra e do terror? Por fim, não seria relevante futuramente problematizar e analisar aprofundadamente o facto de os artistas reviverem ou representarem pessoas sírias, com a violência simbólica que isso acarreta? Ou, noutro sentido, que validade política ou autenticidade possui a representação do outro e das suas emoções e traumas quando o corpo que os representa não os viveu ou sentiu nem tão-pouco é um corpo autobiográfico? Será que a reprodução da violência em cena a partir de mecanismos e formatos estético-performativos faz com que esta seja mais dificilmente abarcada numa noção de "banalização do mal", possibilitando assim que esta possua uma potência crítica que se afasta do "niilismo da transparência"?

Ainda, uma questão relevante a considerar no seio da antropologia da performance é de que modo a actracção pelo real ou pela guerra enquanto palco da performance e a violência estrutural e simbólica que a representação desta acarreta pode, tal como destaca Nuno Crespo, levar a uma reconfiguração das ideias de criatividade, arte e experiência estética? (Crespo, 2017). De que modo a mise-en-scène da guerra permite criar novas formas de soberania, micropolíticas e contrapoder? Poder-se-á estar a assistir a uma afirmação de novos formatos de experiência estética nos quais o corpo 
na dança já não é suficiente enquanto expressão da representação de um real que caminha para uma política do chão como entendimento do político? Ou poder-se-á colocar a questão ao contrário: será que a linguagem do teatro já não é suficiente para expressar o real e nesse sentido recorre à abstração característica da dança como forma de problematizar um real que se refaz constantemente a cada dia? Como se representa um acontecimento ainda a decorrer no nosso tempo histórico? Será que a linguagem da dança poderá surgir no teatro como estratégia fixa de actualização do acontecimento mediante a plasticidade que o caracteriza e que se vai constantemente re-moldando consoante o desenrolar dos eventos?

\section{Notas}

1 Por decisão pessoal, a autora do texto não escreve segundo o novo acordo ortográfico.

2 Refira-se que uma referência importante em torno da temática da emergência do real é a obra The return of the real: the avant-garde at the end of the century (1996), de Hal Foster, que nos alerta para o redirecionamento etnográfico na arte contemporânea, ou seja, para uma deslocação da realidade enquanto efeito da representação para o real enquanto forma de relação com o traumático. Fala-nos, neste sentido, numa arte quase antropológica no sentido em que instrumentaliza a realidade enquanto produto cultural que é interpretado e utilizado no seu potencial político transformador (Foster, 1996).

3 A definição de "corpo sem órgãos" de Artaud (1983) foi difundida na emissão radiofónica Para por fim ao juízo de Deus, proibida em 1948 pela Rádio difusão francesa.

4 Apropriação do conceito de Traverso de "memórias fortes" e "memórias fracas" (Traverso, 2012).

\section{Referências}

Alonso, M. G. (2015). El descanso de los muertos. Territorios del morir y del permanecer. In P. Godinho, I. Fonseca, \& J. Baía (Orgs.), Resistência e/y memória - Perspectivas Ibero-Americanas (pp. 315-324). Lisboa: IHC-FCSH/UNL.

Andrade, G. (2011). A guerra civil síria e a condição dos refugiados: Um antigo problema reinventado pela crueldade de um conflito marcado pela inação da comunidade internacional. Revista de Estudos Internacionais, 2(2), 121-138.

Arendt, H. (2014 [1969]). Sobre a violência. Lisboa: Ed. Relógio D’Água.

Artaud, A. (1983). O teatro e seu duplo. São Paulo: Martins Fontes.

Atkinson, P. (2010). Making opera work: Bricolage and the management of dramaturgy. Music and Arts in Action, 3(1), 3-19.

Balandier, G. (Ed.) (1982). O poder em cena. Brasília: Editora Universidade de Brasília. Barba, E. (1995). A arte secreta do actor: Dicionário de antropologia teatral. Brasil: Unicamp. Bourdieu, P. (2002). A dominação masculina. Rio de Janeiro: Bertrand Brasil. 
Burgess, R., (1997 [1984]). A pesquisa de terreno. Uma introdução (pp. 111-133; 181-200). Lisboa: Celta.

Cedeño, J. (2010). Arte y política. Entre propaganda y resistência. Anuario Colombiano de Historia Social y de la Cultura, 37(2), 221-243.

Cerbino, B. (2009). Dança e memória: Usos que o presente faz do passado. In I. Bogéa (Org.), Primeira estação: Ensaios sobre a São Paulo Companhia de Dança (pp. 33-47). São Paulo: Imprensa Oficial do Estado de São Paulo.

Chagas, G. (2014). A(s) estrada(s) para Damasco: Reflexões sobre as experiências de trabalho de campo em uma sociedade do Oriente Médio. Revista Antropolítica, (37), 403-423.

Conz, R. (2012). A criação em cena: Memórias, percepções e imagens que emergem do corpo que dança. Revista aSPAs, (1), 58-65.

Debord, G. (2003). A sociedade do espetáculo. São Paulo: Coletivo Periferia.

Deleuze, G. \& Guattari, F. (1997). Mil platôs. Capitalismo e esquizofrenia, Vol. 3 (pp. 34-715). Rio de Janeiro: Editora.

Dias, A. C. (2015). Este lugar de memória. O corpo-arquivo na dança contemporânea (Tese de doutoramento). Universidade do Porto, Faculdade de Belas Artes, Porto, Portugal.

Douglas, M. (Ed.) (1978). Los dos Cuerpos. Símbolos naturales (pp. 89-109). Madrid: Ed. Alianza Universidad.

Espinosa Arango, M. (2007). Memoria cultural y el continuo del genocidio: Lo indígena en Colombia. Antípoda. Revista de Antropología y Arqueología, (5), 53-73. Disponível em http:/ / www.redalyc.org/articulo.oa?id=81400504

Félix dos Santos, C., et al. (2016). A memória escrita no ar: Dança enquanto memórias das experiências humanas. Comunicação apresentada no X Seminário Nacional do HISTEDBR - Contribuições para a história e historiografia da educação brasileira, Campinas, Brasil.

Foster, H. (1996). The return of the real: The avant-garde at the end of the century. London: The MIT Press.

Foucault, M. (Ed.) (1987). Os corpos dóceis. Vigiar e punir: Nascimento da prisão (pp. 162-194). Petrópolis: Vozes.

Fradique, T. (2016). A atracção dramatúrgica pelo real. Etnografias do actor-não-actor (Tese de doutoramento) (pp. 2-307). Universidade Nova de Lisboa, Faculdade de Ciências Sociais e Humanas, Lisboa, Portugal.

Furtado, B. (2012). Corpo-arquivo nas obras fílmicas de Sigalit Landau e Marina Abramovic. Comunicação apresentada na Bienal de Dança de Fortaleza - O corpo, lugar da memória, Fortaleza, Brasil. Disponível em http:/ / media.wix.com/ugd/c6daf0_56bd584a6effedd4a95cf90cd0406014.pdf

Galito, M. S. (2013). Terrorismo: Conceptualização do fenómeno. Lisboa: CESA.

Garcia, C. F. (2012). Memória e representação (através) do corpo (Dissertação de mestrado). Universidade Nova de Lisboa, Faculdade de Ciências Sociais e Humanas, Lisboa, Portugal.

Godinho, P. (2013). Anti-sepulcro. Desprivatização de memórias, memória pública e contra-hegemonias. In D. Pereira (Ed.), Emigrantes, exilados e perseguidos: A 
comunidade portuguesa na Galiza (1890-1940) (pp. 203-213). Santiago de Compostela: Através Editora.

Godinho, P. (Ed.) (2014a). Antropologia e performance - Agir, atuar, exibir (pp. 9-24; 193-213). Castro Verde: 100Luz.

Godinho, P. (2014b). Tempo, memória e resistência. In P. Godinho, I. Fonseca, \& J. Baía (Eds.), Resistência e/y memória - Perspectivas Ibero-Americanas (pp. 5-15) [PDF].

Disponível em https:/ / run.unl.pt/bitstream/10362/16123/1/Resiste\%CC\%82ncia\%20e\%20Mem o\%CC\%81ria.\%20Perspectivas\%20Ibero-americanas.pdf

Goffman, E. (2011 [1959]). A representação do eu na vida cotidiana (pp. 1-40). Petrópolis, RJ: Editora Vozes.

Gomes, M. (2016). Eu sou mediterrâneo: Um espectáculo sobre a banalidade do mal (Dissertação de mestrado). Instituto Politécnico de Lisboa, Escola Superior de Teatro e Cinema, Portugal.

Gordon, A. (1997). Ghostly matters. Minneapolis: University of Minnesota Press.

Huntington, S. P. (S.d). O choque de civilizações?. Disponível em

http://www.textosdehistoria.xpg.com.br/unidade_V_texto_10_huntington_o_cho que_de_civilizacoes.pdf

Lepecki, A. (2011). Coreopolítica e coreopolícia. ILHA, 13(1), 41-60.

Lepecki, A. (2013). Planos de composição: Dança, política e movimento. In P. Raposo, et al. (Eds.), A terra do não-lugar. Diálogos entre antropologia e performance (pp. 109-120). Florianópolis: Editora UFSC.

Lopes, B. (2009). A performance da memória. Revista Sala Preta, 9, 135-145.

Nora, P. (1993 [1984]). Entre memória e história. A problemática dos lugares. Projeto História. Revista do Programa de Estudos de Pós-Graduados de História, 10, 7-28.

Peralta, E. (2007). Abordagens teóricas ao estudo da memória social: Uma resenha crítica, Arquivos da Memória, (2) 4-22.

Peralta, E. (2014). O monumento aos combatentes: A performance do fim do império no espaço sagrado da Nação. In P. Godinho (Org.), Antropologia e performance - Agir, atuar, exibir (pp. 203-234). Castro Verde: 100Luz.

Porpino, K. (2010). Corpo, dança e memória: Territórios convergentes. Comunicação apresentada no VI Congresso de Pesquisa e Pós-Graduação em Artes Cénicas, Natal, Brasil.

Prinzac, M. (2005). Performance da dor (Dissertação de mestrado). Universidade do Rio de Janeiro, Centro de Lestras e Artes, Rio de Janeiro, Brasil.

Said, E.W. (1995). Orientalismo. Lisboa: Portugal.

Santinho, M. C. (2009). Reconstruindo memórias: Jovens refugiados em Portugal. Saúde e Sociedade, 18(4), 582-589.

Schechner, R. (1986). Victor Turner's last adventure. In V. Turner (Ed.), The anthropology of performance (pp.7-20). NY: PAJ Publications.

Schechner, R. (Ed.) (2006). What is performance?. Performance studies: An introduccion (pp. 28-51). New York/London: Routledge. 
Scott, J. (2000 [1990]). Los dominados y el arte de la resistencia (pp. 17-71; 167-237). Mexico: Ediciones ERA.

Souza, M. L. (2008). Cinema, ditadura e memória: Questões para uma antropologia do cinema narrativo. Comunicação apresentada na $26^{\mathrm{a}}$ Reunião Brasileira de Antropologia, Porto Seguro, Bahia, Brasil.

Taylor, D. (2000). El espectáculo de la memoria: Trauma, performance y política. Teatro al Sur, (15), 33-40.

Traverso, E. (Ed.) (2012). O tempo e a força. O passado, modos de usar: História, memória e política (pp. 55-71). Lisboa: Edições Unipop.

Turner, V. (1974 [1969]). O processo ritual: Estrutura e anti-estrutura (pp. 9-13; 116-160). Petrópolis, RJ: Vozes.

Turner, V. (Ed.) (1986). The anthropology of performance. The anthropology of performance (pp. 72-89). NewYork: PAJ Publications.

Van Gennep, A. (1978). Os ritos de passagem (pp. 9-33). Petrópolis, RJ: Vozes.

Vier Munhoz, A. (2015). Entre corpo e lugar: Dançar o chão. ALEGRAR, (16).

Zili, G., \& Santos, C. (2015). A produção artística através das memórias políticas: Uma elaboração de novas memórias. XIV Seminário de História da Arte, 14(5), 01-14.

\section{Entrevistas}

Camacho, M. (2016, 12 de Julho). A dança em Eu Sou Mediterrâneo. Lisboa, Café O Archote. 1 Ficheiro. MP3 (15 min.), Entrevista concedida a Sílvia Raposo.

De Campos, A., Rolo, F., \& Dias, B. (2016, 9 de Agosto). A dança em Antes que matem os elefantes. Lisboa, Teatro Nacional D. Maria II. 2 Ficheiros. MP3 (74 min.), Entrevista concedida a Sílvia Raposo.

Gomes, M. (2016, 14 de Agosto). A encenação em Eu Sou Mediterrâneo. Lisboa, Lumiar. 2 Ficheiros. MP3 (60 min.), Entrevista concedida a Sílvia Raposo.

Pires, A. (2016). A Louca em Eu Sou Mediterrâneo. Comunicação pessoal [em linha], 05 agosto.

Roriz, O. (2016, 26 de Julho). O espectáculo Antes que matem os elefantes. Lisboa, Estúdio Palácio Pancas Palha. 4 Ficheiros. MP3 (1h30 min.), Entrevista concedida a Sílvia Raposo.

Data de submissão: 08/11/2017 | Data de aceitação: 21/12/2017 